\title{
Communication
}

[Comunicação]

\section{Death of two slender-billed parakeet (King) (Enicognathus leptorhynchus) (Aves, Psittacidae) by Ascaridia hermaphrodita (Froelich, 1789, Railliet \& Henry, 1914) at the National Zoo of Santiago, Chile}

\author{
[Morte de dois psitacideos (king) Enicognathus leptorhynchus) (Aves, Psittacidae) por Ascaridia \\ hermaphrodita(Froelich, 1789, Railliet \& Henry, 1914) no Zoológico Nacional de Santiago, Chile] \\ D. González-Acuña ${ }^{1}$, M. Fabry' ${ }^{2}$, A.A. Nascimento ${ }^{3}$, J.H. Tebaldi ${ }^{3}$ \\ ${ }^{1}$ Facultad de Medicina Veterinaria - Universidad de Concepción \\ Casilla 537 \\ Chillán, Chile \\ ${ }^{2}$ Zoológico Nacional - Parque Metropolitano de Santiago - Santiago \\ ${ }^{3}$ Faculdade de Ciências Agrárias e Veterinárias - UNESP - Jaboticabal, SP
}

The Chilean psittacids are represented by four species: Cyanoliseus patagonus, Enicognathus ferrugineus, Bolborhynchus aurifrons and the endemic species Enicognathus leptorhynchus. These species are permanently endangered due to trafficking and the degradation of their natural habitats. Many of the Psittacids taken to the Zoo have been confiscated by the Servicio Agrícola y Ganadero (SAG) from private owners who have illegally held them as pets. E. leptorhynchus is listed as endangered in Central Chile, vulnerable in Southern Chile and a species whose conservation status is inadequately known in Southernmost Chile.

No report exists on helminth fauna in Psittacids in Chile. In Brazilian parrots, however, helminths have been reported by various authors (Serra-Freire and Bianchin 1978; Pinto et al. 1993, Vicente et al. 1995, Barros et al. 2002).

The presence of helminths in two captive female specimens of the slender-billed parakeet, found dead at the National Zoo of Santiago de Chile is reported. Previous to their deaths, the parakeets showed signs of watery feces. During their necropsies many nematodes specimens were collected from the small intestine where serious lesions, congestion of the intestinal mucous and an increase of mucous production were observed.

The nematodes were put in hot alcohol $70 \%$ and, afterwards, treated with creosote to make them clear. Then, they were examined, measured, identified as Ascaridia hermaphrodita, and stored in the helminthological collection of the University of Concepción, Chile.

Froelich (1789) described a parasite collected in the intestines of psittacides as Ascaris hermaphrodita, included in the superfamily Ascaridoidea. Later, the genus Ascaris was changed to the genus Ascaridia. $A$. hermaphrodita has been reported as one of the most common nematode species that infect psittacid hosts (Serra-Freire and Biachin, 1978; Pinto et al., 1993). A. hermaphrodita is present in a wide range of hosts and localities, having been discovered in various species of Psittacids in Brazil, in some species of Psittacids in Russia, in Psittacus aestiva in Europa, in Amazona, Ara, Aratinga, Cacatua, Pionus and Pyrrhura in Brazil, Mexico and British Guayana (SerraFreire and Bianchin, 1978). In Brazil, according to Serra-Freire and Bianchin (1978), $A$. hermaphrodita occurs in twelve species of

Recebido em 25 de outubro de 2004

Aceito em 13 de dezembro de 2006

E-mail: danigonz@udec.cl 
psittacids. Martinez et al. (1999) found helminth parasites in a captive Hyacinthine Macaw (Anodorhynchus hyacinthinus) in Argentina, but they only refer to it as Ascaridia spp. This record represents the first report of the nematode in slender-billed parakeet and the first report of the presence of the $A$. hermaphrodita in Chile.

The birds shared a bird cage with an Austral Parakeet (Enicognathus ferrugineus). A contiguous cage containing other SouthAmerican psittacids (Aras, Aratinga and Amazonas) undergoing treatment for parasites. It is not known whether the parasites in $E$. leptorhynchus were acquired in the wild or in the Zoo. Before the source of their infection be known, it will be necessary to check if other captive psitacid birds have the parasite and if $A$. hermaphrodita is currently present in the wild in Chile.

Keywords: psittacid, Enicognathus leptorhynchus, nematode, Ascaridia hermaphrodita, Chile

\section{RESUMO}

No Zoológico Nacional do Parque Metropolitano de Santiago, Chile, foram encontrados dois psitacídeos Enicognathus leptorhynchus, mortos pelo nematódeo Ascaridia hermaphrodita (Froelich, 1789). Este é o primeiro registro desse nematódeo em E. leptorhynchus e também o primeiro registro deste parasito no Chile.

Palavras-chave: psitacídeos, Enicognathus leptorhynchus, nematódeo, Ascaridia hermaphrodita, Chile

\section{ACKNOWLEDGEMENT}

We thank Dr. Brigitte Frank for the critical review of the manuscript and Darci Batesti for the abstract in portuguese

\section{REFERENCES}

BARROS, L.A.; LUZES, L.P.; ALMEIDA, F.M. et al. First case report of Ascaridia hermafrodita (Froelich, 1789) Railliet \& Henry, 1914 (Nematoda, Ascaridoidea) in the Brazilian hyacinth macaw, Anodorhynchus hyacinthinus (Latham, 1790) Spix, 1824 (Aves, Psitacidae). Rev. Bras. Cien. Vet., v.9, p.114-115, 2002.

MARTÍNEZ, F.A.; TROYANO J.C.; BINDA, J.L. et al. Infestación por Capillaria y Ascaridia spp. en psitacidos de criadero. Rev. Med. Vet., v.80, p.24-26, 1999.
PINTO, R.M.; VICENTE, J.J.; NOROÑA, D. Nematode parasites of Brazilian psittacid birds, with emphasis on the genus Pelecitus Railliet \& Henry, 1910. Mem. Inst. Oswaldo Cruz, v.88, p. 279-284, 1993.

SERRA-FREIRE, N.M.; BIANCHIN, I. Sobre quatro especies de Ascaridia (Dujardin, 1845) parasitas de psitacideos, com citaçao de um novo hospedeiro para A. hermaphrodita (Froelich, 1789) Nematoda: Ascaroidea) no Brasil. Atas Soc. Biol. Rio de Janeiro, v.19, p.51-54, 1978.

VICENTE, J.J.; RODRIGUES H.O; GOMES D.C., et al. Nematoides do Brasil. Parte IV. Nematoides de aves. Rev. Bras. Zool., v.12, supl. 1, p. 1-273, 1995. 